\title{
TANGGUNG JAWAB HUKUM AMERIKA SERIKAT DAN INDONESIA ATAS PENAHANAN TANPA BATAS WAKTU DAN TANPA PROSES PERADILAN YANG FAIR TERHADAP HAMBALI (WNI) DI PENJARA GUANTANAMO BAY KUBA
}

\author{
Ridarson Galingging
}

Fakultas Hukum Universitas Yarsi

Email: ridarson@yahoo.com

\begin{abstract}
ABSTRAK
Artikel ini akan mengeksplorasi dan membuktikan bahwa penahanan tanpa batas waktu (indefinite detention) dan penahanan tanpa proses peradilan yang fair (detention without fair trial) serta berbagai bentuk perlakuan yang tidak manusiawi (inhuman treatment) yang telah dilakukan otoritas Amerika Serikat (AS) terhadap para tahanan, khususnya Hambali (WNI) di penjara Guantanamo dapat dikategorikan sebagai pelanggaran terhadap Hukum Humaniter Internasional (International Humanitarian Law) dan Hukum HAM Internasional (International Human Rights Law). Penulis juga akan memperlihatkan dan membuktikan bahwa tidak hanya pemerintah AS yang dapat dimintakan pertanggung jawaban hukumnya, tetapi pemerintah Indonesia pun dapat dimintakan pertanggung jawaban hukumnya atas pelanggaran terhadap hukum nasional yaitu UU No.37 Tahun 1999 Tentang Hubungan Luar Negeri dan UU No.39 Tahun 1999 Tentang Hak Asasi Manusia.
\end{abstract}

Kata Kunci: Guantanamo, Penahanan, Hukum Humaniter Internasional, Hukum HAM Internasional

\begin{abstract}
This article demonstrates that indefinite detention, detention without trial, and inhuman treatment perpetrated by U.S. authorities against detainees at the Guantanamo Bay Prison in Cuba, especially against Hambali (an Indonesian citizen), can be classified as a violation of international humanitarian law and international human rights law. The article also shows that both the U.S. government and the Indonesian government are legally responsible for these violations. The Indonesian government, in the case of Hambali's detention at Guantanamo Bay Prison, violated Indonesian domestic Law No.37/1999 on Foreign Relations and Law No.39/1999 on Human Rights.
\end{abstract}

Key Words: Guantanamo, Detention, International Humanitarian Law, International Human Rights Law 


\section{PENDAHULUAN}

Buntut dari serangan teroris terhadap Amerika Serikat (AS) pada tanggal 11 September 2001, hampir delapan ratus orang yang berasal dari paling tidak empat puluh negara ditangkap dan ditahan oleh Pemerintah AS baik itu di wilayah AS sendiri maupun di berbagai penjuru dunia. Penangkapan itu diakui langsung oleh Presiden Bush. 'President Bush acknowledges that the CIA has held suspected terrorists in secret prisons overseas. ${ }^{1}$ Orang-orang yang ditangkap dan ditahan terkait serangan teroris ini ada yang ditempatkan diberbagi penjara di banyak negara, sebelum dipindahkan ke Guantanamo. Sampai sekarang masih banyak yang belum dibawa ke Pengadilan, terutama mereka-mereka yang bukan warga negara AS dan ditempatkan di Guantanamo Bay, suatu Penjara yang secara yuridis berada di wilayah Negara Cuba, tetapi dibawah kontrol AS.

Hampir tujuh belas tahun telah berlalu sejak Guantanamo dibuka pada 2002 hingga saat penulisan ini pada April 2019, sudah tiga presiden AS yang berkuasa yang dimulai dari George W. Bush (2001-2009) yang kemudian dilanjutkan oleh presiden Barrack Obama (2009-2017) dan pada saat ini dibawah pemerintahan presiden Donald Trump, masih ada para tahanan yang tetap ditahan oleh pemerintah AS dan belum juga ada kepastian kapan mereka akan dibawa ke Pengadilan dan sampai berapa lama lagi mereka akan dikenakan penahanan di Guantanamo Bay ini. Jelas secara hukum baik itu hukum domestik AS maupun hukum internasional, penahanan tanpa batas waktu dan tanpa proses peradilan yang fair ini merupakan suatu pelanggaran Hak Asasi Manusia (HAM) dan pemerintah AS harus dimintakan pertanggung jawabannya.

Diantara ratusan para tahananan terkait terorisme internasional yang ditempatkan oleh AS di Guantanamo Bay ini ada Hambali, seorang Warga Negara Indonesia (WNI). Hambali ditangkap oleh badan intelijen AS CIA dan Otoritas Hukum Thailand pada 14 Agustus tahun 2003. Disamping tuduhan terkait dengan serangan 11 September 2001, Hambali sebenarnya juga merupakan buron Mabes Polri terkait dengan serangan Bom Bali I di Kuta pada 2002 yang menewaskan 202 orang dan peledakan Hotel JW Marriot pada 2003 di Jakarta.

\footnotetext{
${ }^{1} \mathrm{CNN}$ Library, Guantanamo Bay Naval Station Fast Facts, https://www.cnn.com September 11, 2018 diakses 12 Januari 2019
} 
Jadi setelah ditangkap di Thailand tersebut Hambali tidak diserahkan oleh AS kepada pemerintah Indonesia tetapi ditempatkan di tahanan rahasia CIA untuk beberapa tahun dan di Guantanamo Bay sejak 4 September 2006 menurut media VOA. ${ }^{2}$ Pemerintah RI ada melakukan upaya untuk meminta supaya Hambali diserahkan saja kepada pemerintah RI untuk diadili di Indonesia, tetapi permintaan RI ini ditolak oleh AS dan sekarang tidak kedengaran lagi tentang apa yang telah dilakukan oleh pemerintah RI untuk memulangkan Hambali ke Indonesia untuk diproses hukum dan diadili oleh pengadilan Indonesia. ${ }^{3}$

Kecaman terhadap penahanan tanpa batas waktu dan tanpa proses peradilan serta terjadinya berbagai bentuk perlakuan tidak manusiawi yang dilakukan oleh AS di Guantanamo Bay ini telah banyak dilontarkan oleh pemerintah dari berbagai negara, Lembaga Swadaya Masyarakat (LSM) seperti Amnesty Internasional dan Human Rights Watch, Human Rights First dan bahkan oleh Perserikatan Bangsa Bangsa (PBB) serta Komite Palang Merah Internasional (ICRC). Disamping penahanan tanpa batas waktu dan tanpa proses peradilan, kecaman dari masyarakat internasional terhadap AS juga terkait dengan terjadinya berbagai jenis pelanggaran HAM serius lainnya terhadap para tahanan di Guantanamo ini. Tapi tampaknya AS mengabaikan begitu saja semua kecaman masyarakat internasional ini.

Dalam tulisan ini penulis akan mencoba untuk mengeksplorasi dan membuktikan bahwa penahanan tanpa batas waktu, penahanan tanpa proses peradilan dan perlakuan yang tidak manusiawi serta merendahkan harkat dan martabat manusia (inhuman and degrading treatment) yang telah dilakukan oleh otoritas AS terhadap para tahanan yang berada di Penjara Guantanamo Bay tersebut dapat dikategorikan sebagai pelanggaran terhadap ketentuan-ketentuan Hukum Humaniter Internasional (International Humanitarian Law, IHL) dan Hukum HAM Internasional (International Human Rights Law, IHRL) serta akan memperlihatkan pula bahwa AS bisa dimintakan pertanggungjawaban hukumnya atas pelanggaran tersebut. Selanjutnya Penulis akan membuktikan pula secara

${ }^{2}$ VOA, Napi Indonesia di Guantanamo Pertama Kali Tampil di Publik, https://www.voaindonesia.com 19 Agustus 2016, diakses 5 Januari 2019

${ }^{3}$ VOA, Hambali Ancaman Keamanan Tinggi Amerika, https://www.voaindonesia.com 18 Maret 2016, diakses 5 Januari 2019 
yuridis bahwa pemerintah RI dapat dimintakan pertanggunjawaban hukumnya terhadap pelanggaran hukum nasional yaitu UU No.37 Tahun 1999 Tentang Hubungan Luar Negeri dan UU No.39 Tahun 1999 Tentang Hak Asasi Manusia terkait dengan seorang WNI yang bernama bernama Hambali. Hambali telah di tahan tanpa batas waktu (indefinite detention) dan ditahan tanpa proses peradilan yang fair (detention without trial) serta diperlakuan secara tidak manusiawi di penjara Guantanamo Bay selama lebih kurang enam belas tahun dan sampai dengan saat penulisan ini pada April 2019 belum ada kepastian juga tentang kapan dia akan dibawa ke muka pengadilan, baik itu pengadilan AS ataupun pengadilan Indonesia bahkan harus dibebaskan jika tidak ada cukup bukti-bukti yang kuat yang dapat dipergunakan untuk menuntut dan menghukumnya.

\section{PEMBAHASAN}

\section{A.Fakta Seputar Guantanamo}

Presiden AS George W. Bush membuka Guantanamo sebagai tempat bagi tersangka teroris setelah serangan teroris 11 September 2001 berdasarkan 'Military Order' tanggal 13 November 2001 tentang 'Detention, Treatment, and Trial of Certain non Citizens in the War against Terrorism'. ${ }^{4}$ Guantanamo digunakan sebagai tempat untuk menampung dan menginterogasi para tersangka terkait serangan 11 September yang diberi lebel 'enemy combatans' yang ditangkap di Afghanistan dan Pakistan serta berbagai tempat lainnya di berbagai penjuru dunia. Para tersangka ini adalah bagian dari al Qaeda dan Taliban ataupun para pihak yang mendukungnya.

Para tahanan yang berada di Guantanmo ini pertama kalinya dikirim pada bulan Januari 2002 dengan jumlah yang mencapai delapan ratus orang. Disamping itu, Presiden Bush mengakui juga bahwa selain di penjara Guantanamo, badan intelijen AS CIA masih memiliki tempat-tempat penahan terhadap para tersangka teroris yang ditangkap diberbagai negara . Merekamereka ini ada yang berasal dari Azerbaijan, Kenya, Thailand dan Turki, Indonesia, Yaman, Saudi Arabia. Mereka semua akhirnya di transfer ke

${ }^{4}$ Presidential Documents, 'Military Order of November 13, 2001, on the Detention, Treatment and Trial of Certain Non-Citizens in the War against Terrorism' (Federal Register, 16 November 2001) 
Guantanamo. Adapun lebel yang diberikan kepada para tahanan di Guantanamo ini adalah 'enemy combatant', yang di dalam ketentuan 'Military Order' tanggal 13 November 2001 tersebut diatas didefinisikan sebagai berikut:

"an individual who was part of or supporting Taliban or al Qaeda forces, or associated forces that are engaged in hostilities against the United States or its coalition partners.This include any person who has committed a belligerent act or has directly supported hostilities in aid of enemy armed forces.",5

Lebel 'enemy combatants' diberikan kepada para tersangka teroris di Guantanamo tersebut karena menurut AS kepada mereka tidak diberlakukan Konstitusi AS dan hukum pidana biasa. Perlindungan HAM juga tidak berlaku terhadap mereka-mereka ini. Lebih jauh lagi, pengadilan umum AS juga tidak memiliki jurisdiksi untuk mengadili mereka. Kepada mereka yang disangka teroris ini akan diadili oleh 'Military Commission'. Adapun 'military commission" itu merupakan suatu bentuk tribunal militer yang bentuknya berbeda serta beroperasi secara mandiri dari sistem peradilan militer AS. " $A$ commission is a form of military tribunal and is distinct from and operates independently from the U.S. military justice system". ${ }^{6} \mathrm{Jadi}$ dari awalnya tempat penahanan militer Guantanamo ini memang dibentuk untuk berada diluar jangkauan sistem peradilan biasa AS (the reguler US justice system ).

Terkait dengan berbagai isu hukum dan pelanggaran HAM yang dipersoalkan terhadap para tahanan yang ditempatkan di Guantanamo ini penting sekali untuk dicermati apa yang diungkapkan oleh Organisasi pemerhati HAM AS yang memiliki reputasi sangat baik sekali dan selalu aktif memonitor perkembangan para tahanan teroris Guantanamo 'Human Rights Watch' yang didalam laporannya mengatakan bahwa:

"Nearly all of those detained at Guantanamo since its inception have, for one reason or another, been held in violation of applicable international humanitarian law or international human rights law. Detainees were held without regard for their legal status under the laws of war. Very few were charged with a criminal offence. Many were tortured or otherwise ill-treated, were held based on inaccurate evidence or analysis, or on

\footnotetext{
${ }^{5}$ Amnesty International, USA: Different label, same policy? Administration drop's 'enemy combatant' label in Guantanamo litigation, but retains law of war framework for detentions, https://www.amnesty.org, 16 March 2009 diakses 5 January 2019

American Bar, The U.S. Military Commission: Looking Forward, 2018 https://www.americanbar.org diakses 21 Janury 2019
} 
misinformation, or were cases of mistaken identity, and were not provided with adequate means to challenge their detention. These violations have damaged the US human rights record and undermined the fight against extremist groups by feeding into terrorist propaganda and providing them a powerful recruitment tool." 7

Perlakuan terhadap para tahanan di Guantanamo ini menurut 'Human Rights Watch" sama sekali tidak memperdulikan ketentuan-ketentuan hukum HAM internasional dan hukum humaniter internasional. Mereka ditahan tanpa memperhatikan Status mereka dalam hukum perang. Sedikit sekali yang dikenakan tuduhan melakukan suatu kejahatan. Banyak yang disiksa atau diperlakukan secara menyakitkan, ditahan dengan dasar bukti atau analisa yang tidak akurat, atau informasi yang salah, atau karena identitas yang keliru, dan tidak memiliki sarana yang memadai untuk menguji keabsahan penahanan mereka. Pelanggaran-pelanggaran yang dilakukan di Guantanamo ini telah merusak citra perlindungan HAM di Amerika Serikat dan melemahkan pula upaya pemberantasan kelompok-kelompok ekstrimis.

Hasil penelitian dan investigasi Human Rights Watch tersebut menyebutkan juga bahwa militer AS, sebagai bagian dari tekhnik interogasi mereka terhadap para tahanan, telah melakukan penyiksaan, perlakuan yang tidak manusiawi seperti menempatkan para tahanan ini dalam posisi-posisi yang menyakitkan, pengisolasian (solitary confinement), ancaman akan disiksa, dimatikan, dan diserang anjing militer, pengurangan jam tidur, diekspos dalam jangka waktu yang lama di tempat yang sangat panas, dingin, dan bising.

Perlakuan-perlakuan yang sangat kejam dan tidak manusiawi terhadap para tahanan di Guantanamo seperti yang disebutkan diatas telah menimbulkan berbagai kecaman keras dari dunia internasional. Komite PBB yang menentang Penyiksaan (the UN Committee against Torture) dan para pejabat HAM PBB, LSM HAM seperti Human Rights Watch, Amnesty Internasional, Palang Merah Internasional (ICRC) dan banyak pemimpin negara-negara juga telah meminta kepada AS agar segera mengakhiri penahanan di Guantanamo dan menutup penjara tersebut.

${ }^{7}$ Human Rights Watch, $Q$ \& A: Guantanamo Bay, US Detentions, and the Trump Administration, https://www.hrw.org, June 27, 2018 diakses 5 Januari 2019 
Reaksi dunia yang tidak bisa menerima keberadaan penjara Guantanamo yang telah melanggar hukum humaniter internasional dan hukum HAM internasional tersebut menjadi salah satu alasan mengapa presiden Obama mengeluarkan Executive Order 13492 pada 22 Januari 2009. Melalui Executive Order tersebut presiden Obama memerintahkan penutupan penjara Guantanamo. Sebagai bagian dari proses penutupan Guantanamo tersebut dibentuklah suatu satuan tugas (task force) untuk melakukan review terhadap semua berkas-berkas (files) dari para tahanan yang ada di Guantanamo.

Pada bulan Maret 2011, presiden Obama mengganti CSRTs (the Combatant Status Review Tribunals) dan ARBs (the Administrative Review Boards) yang dibentuk dibawah pemerintahan presiden Bush dan memiliki kewenangan untuk melakukan peninjauan ulang terhadap status tahanan para tersangka teroris di Guantanamo dengan badan baru yang bernama PRBs (the Periodic Review Boards). Sebagai mana yang telah sering dikritik, persidanganpersidangan CSRTs tidak bersifat independen dan tidak memiliki perlindunganperlindungan secara prosedur yang diperlukan bagi suatu peninjauan ulang (review) yang baik, kurangnya akses terhadap pengacara, sedikit atau tidak adanya akses terhadap alat bukti yang digunakan terhadap para tahanan, tidak adanya ketentuan untuk mengenyampingkan alat bukti yang diperoleh dengan menggunakan kekerasan. ${ }^{8}$

ARBs merupakan suatu prosedur peninjauan ulang administratif tahunan yang dilakukan oleh suatu suatu dewan pengurus yang beranggotakan para tentara ('board of military officers'), untuk menilai apakah seorang tahanan itu (the enemy combattan) merupakan ancaman terhadap AS atau sekutu-sekutunya atau apakah ada faktor-faktor lainnya untuk tetap melakukan penahan terhadap yang bersangkutan, seperti 'nilai intelijens' (intelligence value) dari tahanan yang bersangkutan. Berdasarkan penilaian tersebut bisa direkomendasikan pembebasan, transfer, atau tetap dikenakan penahanan, tetapi jarang sekali dikeluarkan 'rekomendasi' untuk pembebasan. ${ }^{9}$

\footnotetext{
${ }^{8}$ Helen Duffy, The 'War On Terror' and the Framework of International Law, Cambridge University Press, Cambridge, 2015 hal. 678

${ }^{9}$ Ibid, hal.679
} 
Dalam penerapannya kemudian, ternyata badan baru yang dibentuk presiden Obama yang bernama PRBs ini, sedikit sekali membawa perubahanperubahan yang positif. Kalau sebelumnya peninjauan ulang dilakukan setiap tahun, maka pada PRBS peninjauan ulangnya dilakukan dalam waktu setiap enam bulan sekali. Kalau sebelumnya hanya Departemen Pertahan (DOD) saja yang telibat, maka sekarang peninjauan ulang dilakukan oleh beberapa Departemen antara lain Departemen Kehakiman, Departemen Pertahanan, Departemen Luar Negeri, Departemen Keamanan Dalam Negeri, Badan Intelijen Negara dan Kepala Staf Gabungan Angkatan Bersenjata (interagency). Kalau pada ARBs digunakan 'potential inteligence value' sebagai dasar untuk tetap melakukan penahanan atas seorang tersangka, maka hal ini tidak digunakan lagi Pada PRBs. ${ }^{10}$

Komisi Militer (Military Commission) yang dibentuk oleh Presiden berdasarkan Executive Order mengatur perihal peradilan bagi para tersangka teroris yang ditahan di Guantanamo yang bukan berkewarganegaraan AS (noncitizens). Executive Order tersebut secara spesifik tidak memasukkan warga negara AS kedalam jurisdiksi Komisi Militer ini. Adanya pembedaan forum pengadilan yang akan mengadili kejahatan antara warga negara dan non-warga negara AS ini jelas merupakan suatu tindakan diskriminasi dan bertentangan dengan konstitusi AS dan hukum HAM internasional. Kritik juga banyak muncul baik dari dalam AS sendiri maupun dari dunia internasional terkait dengan Komisi Militer dan hukum acara yang digunakannya, seperti yang disebutkan berikut ini:

"The decision to submit to trial by Military Commission in itself, and the specific Rules of Procedure of the Commissions, have given rise to profound criticism within the United States and internationally. Since the rules were first published in March 2002, they have been amended, and somewhat improved, several times. Despite this, at all stages they have provoked concern about 'still failing to provide many of the fundamental elements of a fair trial found in federal civilian courts and a court martial system. " "

Jika kritik diatas terkait dengan sifat diskriminatif hukum acara yang digunakan oleh Komisi Militer, maka pernyataan yang kritis dan tajam dari Human Rights

\footnotetext{
${ }^{10} \mathrm{Ibid}$, hal.680

${ }^{11} \mathrm{Ibid}$, hal.688-689
} 
First dibawah ini menyoroti soal seringnya dakwaan digugurkan, dan penundaan persidangan yang bisa memakan waktu bertahun-tahun:

"Those eager for swift justice against accused terrorism suspects have at times called for sending suspects to the military commission system in Guantanamo based on fears that suspects may be acquitted in a civillian court. But the track record of the Guantanamo Military Commissions demonstrates that they offer anything but swift justice. Charges are routinely dropped and overturned, and the few cases awaiting trial are mired in delays that have dragged on for years. " 12 Walaupun sudah dibentuk sejak 13 November 2001 dengan Military Order tentang Detention, Treatment, and Trial of Certain non-citizens in the War against Terrorism”, baru pada tahun 2003, ada satu kelompok anggota al Qaeda yang ditahan di Guantanamo yang dirujuk untuk diadili dimuka Komisi Militer dan pada tahun 2004 tuduhan-tuduhan yang pertama kalinya diajukan. Tetapi kewenangan Presiden untuk membentuk Komisi Militer ini dipersoalkan ke Mahkamah Agung AS dalam kasus Hamdan v. Rumsfeld. Mahkamah Agung AS memutuskan bahwa 'the military commission convened to try Hamdan lacks power to proceed because its structure and procedures violate both the Uniform Code of Military Justice and the Geneva Conventions." 13 Jadi intinya Komisi Militer ini melanggar 'the Uniform Code of Military Justice, dan Konvensi Jenewa.

Buruknya track record dari Komisi Militer terkait dengan sedikitnya kasus yang diputus dan berlarut-larutnya penangan kasus ini juga dikemukan oleh Human Rights First seperti yang disebutkan dibawah ini:

"The Commissions have an abysmall track record of achieving justice, having attained just eight convictions, three of which have been overturned. Federal civilian courts are much more capable of securing swift justice in terrorism cases. Since 9/11 over six hundred individuals have been convicted of terrorism related crimes in Federal Courts, 99 of whom, like Hambali, were captured overseas. $^{14}$

\footnotetext{
${ }^{12}$ Human Rights First, Dropped Charges, Overturned Convictions, and Delayed Trials in Guantanamo Military Commissions, http://www.humanrightsfirs.org 16 February 2018, diakses 6 Januari 2019

${ }^{13}$ Op.cit, hal. 687

14 Patricia Stoottlemyer, Looking For Justice? Avoid Guantanamo, https://www.humanrightsfirst.org October 29, 2018 diakses 7 Januari 2019
} 
Sejak masa dibentuknya hingga pada saat ini, Komisi Militer memiliki track record yang buruk dari segi jumlah kasus yang bisa diputus. Hanya ada delapan putusan yang dihasilkan, dan tiga dari putusan tersebut kemudian dibatalkan. Pengadilan sipil Federal memiliki kemampuan yang jauh lebih besar dalam hal kecepatan memutus perkara -perkara terorisme. Sejak September 2001 ada lebih dari enam ratus terpidana yang dihukum, sembilan puluh sembilan diantaranya ditangkap diluar wilayah AS. ${ }^{15}$ Jadi tidak hanya persoalan kecilnya jumlah kasus yang disidangkan di Komisi Militer yang jadi masalah, tetapi keberadaan Komisi Militer itu sendiripun telah diuji kemuka pengadilan dalam kasus Hamdan v. Rumsfeld.

Perintah presiden Obama yang terkait dengan penutupan penjara Guantanamo tersebut tidak bertahan lama umurnya. Begitu presiden Obama digantikan oleh presiden Donald Trump, perintah Obama tersebut dibatalkan. Pada 30 Januari 2018 presiden Trump mengeluarkan Executive Order yang disebut "Protecting America Through Lawful Detention of Terrorists. Executive Order tersebut mengatakan "The United States may transport additional detainees to U.S. Naval Station Guantanamo Bay when lawful and necessary to protect the nation." Jadi penjara Guantanamo dibuka kembali, bahkan akan diisi dengan tahanan tambahan jika dirasa perlu. Sejak 1 Mei 2018 tidak ada tahanan tambahan yang dibawa ke Guantanamo. ${ }^{16}$

\section{B. Kerangka Hukum}

Hukum Humaniter Internasional dan Hukum HAM Internasional berlaku terhadap para tahanan di penjara Guantanamo ini. Pakar hukum internasional Helen Duffy mengatakan bahwa sepanjang para tahanan itu ditahan AS dalam konteks atau dalam hubungan dengan suatu konflik bersenjata, kepada mereka diberlakukan ketentuan-ketentuan yang diatur dalam hukum humaniter internasional. AS terikat pada hukum humaniter internasional sebagai pihak dalam konflik bersenjata di Afghanistan terkait dengan orang-orang yang ditahan

\footnotetext{
${ }^{15}$ Ibid

${ }^{16}$ American Bar, The U.S. Military Commissions: Looking Forward, Report May 2018, https://www.americanbar.org. Diakses 21 Jan 2019
} 
karena konflik tersebut. Sebagai tambahan, AS tetap terikat oleh hukum HAM internasional, dalam konteks konflik bersenjata. ${ }^{17}$

\section{Jangkauan Hukum Humaniter Internasional (IHL)}

Dalam konteks para tahanan yang berada di penjara Guantanamo ini, maka ketentuan-ketentuan utama IHL yang relevan adalah ketentuan tentang perlakuan terhadap orang yang ditahan selama terjadinya konflik bersenjata internasional yang terkandung didalam empat Konvensi Jenewa 1949 (GCIGCIV) dan ketentuan yang diatur dalam the First Additional Protocol to the Geneva Conventions 1977 (AP I). ${ }^{18}$

AS, seperti juga Afghanistan merupakan negara peserta dari GC I-GC IV, sehingga mereka terikat padanya sebagai hukum traktat (treat law). AS meratifikasinya pada 2 Agustus 1955, sedangkan Afghanistan pada 26 September 1956. Terhadap traktat-traktat yang tidak diratifikasi oleh AS tetap relevan sepanjang mereka mencerminkan hukum kebiasaan, dan banyak ketentua AP I yang diakui oleh AS dan negara-negara lainnya. Penting juga untuk diperhatikan putusan Mahkamah Pidana Internasional untuk Yugoslavia (ICTY) terkit dengan ruang lingkup berlakunya IHL, seperti yang diungkapkan dibawah ini:

In the context of prisoners of war, the ICTY has noted that 'with respect to prisoners of war, the convention applies to combatants in the power of the enemy; it makes no difference whether they are kept in the vicinity of hostilities'. The key question is whether persons fall under the power or control of one of the parties to the conflict-in this case, whether the Guantanamo detainees are under US control, which is clearly the case. ${ }^{19}$

Dalam putusan tersebut diatas, ICTY menyatakan bahwa yang paling penting terkait dengan pemberlakuan IHL terhadap para tahanan di Guantanamo tersebut apakah para tahanan itu berada dibawah kontrol AS atau bukan. Dalam kasus para tahanan Guantanamo ini jelas bahwa mereka berada dibawah kontrol AS, walaupun lokasi penahanannya berada diluar teritorial AS.

\footnotetext{
${ }^{17}$ Helen Duffy, hal.690-691

${ }^{18}$ Helen Duffy, hal. 692

${ }^{19}$ Helen Duffy, hal. 692-693
} 


\section{Jangkauan Hukum HAM Internasional (IHRL)}

Walaupun banyak diabaikan dalam pembicaraan resmi, AS juga terikat untuk mematuhi baik itu traktat-traktat dimana AS merupakan negara peserta maupun hukum kebiasaan HAM internasional. AS merupakan negara peserta dari International Covenant on Civil and Political Rights (ICCPR) yang mengatur kewajiban-kewajiban HAM yang mengikat terhadap AS, serta terikat pula pada the United Nations Convention against Torture (CAT) dan American Declaration on the Rights and Duties of Man (1948). As telah menandatangani (tetapi tidak meratifikasi) theAmerican Convention on Human Rights (ACHR). ${ }^{20}$ Negaranegara peserta bisa menyimpang dari kewajiban-kewajiban tertentu dari traktattraktat, termasuk ICCPR, atas dasar bahwa mereka menghadapi keadaan darurat yang mengancam kehidupan negaranya. Tetapi AS tidak menggunakan prosedur ini dan karenanya ICCPR berlaku secara keseluruhannya terhadap AS.

Penyimpangan terhadap pemberlakuan ICCPR oleh suatu negara tidak berlaku terhadap hak-hak asasi manusia yang tidak bisa disimpangi atau 'nonderogable human rights'. Termasuk dalam kategori 'non-derogable human rights' yang tidak bisa disimpangi ini adalah hak untuk bebas dari penyiksaan dan perlakuan yang menyakitkan (freedom from torture or illtreatment), dan hak untuk bebas dari pemberlakuan hukum pidana yang berlaku surut (retroactive application of criminal law). Sedangkan hak atas peradilan yang fair dan hak-hak prosedural selama masa tahanan haruslah diberlakukan dan dihormati sepanjang waktu. Jadi secara singkat dapat dikatakan bahwa hampir semua hak-hak penting yang jadi persoalan di Guantanamo terkait dengan hak-hak yang berlaku walaupun dalam keadaan darurat.

Sebagai tambahan terhadap kewajiban-kewajiban traktatnya, AS juga terikat dengan hukum kebiasaan HAM terkait dengan hak-hak yang menjadi persoalan terhadap para tahanan di penjara Guantanamo. Lagi pula, beberapa norma tertentu yang diperbincangkan, terutama norma dilarangnya penyiksaan dan perlakuan yang menyakitkan, atau penahanan sewenang-wenang tanpa batas waktu (pro-longed arbitrary detention), secara umum diakui sebagai norma jus cogens dalam hukum internasional. Tiada keadaan (tentu saja tiada

\footnotetext{
${ }^{20}$ Helen Duffy, hal.693
} 
penyimpangan), yang dapat membenarkan pelanggaran hak-hak dan kewajiban yang sudah berstatus jus cogens. ${ }^{21}$

Terkait dengan penahanan sewenang-wenang tanpa batas waktu ini secara tegas ICCPR dan The Universal Declaration of Human Rights (UDHR) mengaturnya. Pasal 9-15 ICCPR menjamin hak untuk tidak dikenakan penangkapan dan penahanan yang sewenang-wenang dan hak atas peradilan yang fair, sedangkan pasal 9 UDHR mengatakan 'no one shall be subjected to arbitrary arrest, detention or exile' yang artinya "tiada seorangpun akan dikenakan penangkapan ataupun penahanan yang sewenang-wenang ataupun diasingkan." Untuk lebih memperjelas pemahaman kita, pandangan UN Human Rights Committee (HRC), badan yang memonitor ketaatan negara anggota terhadap norma-norma ICCPR terkait dengan penahanan yang sewenang-wenang di Guantanamo ini perlu diperhatikan juga. HRC mengatakan bahwa:

'detentions are arbitrary if not in accordance with due process of law or are manifestly disproportional, unjust or unpredictable. Detention should be consistent with the normal procedures used to prosecute individuals implicated in criminal offences and speedily brought to a fair trial. Instead, US practice has been to empower authorities to detain people indefinitely, without the need to sustain evidence in court or to prove criminal responsibility'. ${ }^{22}$

Pandangan HRC tersebut diatas mengatakan bahwa suatu penahanan itu bersifat sewenang-wenang jika tidak sesuai dengan 'due process of law' atau secara jelas bersifat tidak proporsional, tidak adil atau tidak dapat diprediksikan. Penahanan itu harus konsisten dengan prosedur yang normal berlaku untuk menuntut individu-individu yang terimplikasi suatu tindak pidana dan sesegera mungkin diajukan ke suatu peradilan yang fair. Sebaliknya, praktek AS telah memberikan kekuasaan kepada pihak yang punya otoritas untuk menahan orang tanpa batas waktu yang tertentu, tanpa perlu didukung alat bukti di depan pengadilan atau untuk membuktikan tanggung jawab pidana.

Sedangkan penahanan tanpa batas waktu dan tanpa proses peradilan terhadap para tahanan di Guantanamo ini juga tidak diperlukan, tidak bijak dan merupakan tindakan yang bertentangan dengan konstitusi. Individu-individu yang dianggap bisa membahayakan negara AS bisa ditutntut didepan pengadilan yang

\footnotetext{
${ }^{21}$ Helen Duffy, hal.695

${ }^{22}$ Human Rights Watch, https://www.hrw.org diakses 9 Des 2018
} 
sudah ada didalam sistem peradilan AS sendiri. American Civil Liberties Union (ACLU) menegas hal tersebut, seperti yang terurai berikut:

"Any system of indefinite detention without trial for suspected terrorists would be unnecessary, unwise, and unconstitutional. Individuals who pose a genuine danger to the US can be prosecuted in our existing courts under our existing laws. And any statute that purports to authorize the long-term detention of suspected terrorists on the basis of perceived future dangerousness rather than past criminal conduct will likely be invalidated by our federal courts. ${ }^{23}$

\section{Tanggung Jawab AS Dan RI dalam Kasus Hambali}

Hambali merupakan WNI yang ditangkap di Bangkok pada 14 Agustus 2003 dalam suatu operasi gabungan AS-Thailand. Dia ditempatkan dalam tahanan rahasia CIA yang dikenal sebagai 'Black Sites' selama hampir tiga tahun, dan ditransfer ke Guantanamo pada 4 September 2006. Kalau dihitung dari tahun 2003 sampai dengan saat ini, maka Hambali sudah berada di tahanan AS selama lebih kurang 16 tahun. Suatu masa penahanan yang sangat lama sekali sekali dan sampai saat penulisan ini pada April 2019 belum juga ada kepastian kapan masa penahanannya akan berakhir dan kapan pula perkaranya akan dibawa kemuka pengadilan AS ataupun pengadilan di Indonesia.

Dari pembahasan sebelumnya, terlihat dengan jelas sekali bahwa kebanyakan para tahanan yang ditempatkan di penjara Guantanamo ini telah dikenakan penahanan tanpa batas waktu dan tanpa proses peradilan yang fair. Terjadi banyak sekali tindakan yang tidak manusiawi dan merendahkan harkat dan martabat manusia seperti penyiksaan-penyiksaan yang dilakukan oleh AS terhadap para tahanan Guantanamo untuk mendapatkan pengakuan dan alat bukti terkait dengan serangan teroris 9/11. Penyiksaan-penyiksaan ini secara jelas telah diungkapkan dalam "The Senate intelligence committee's report on the CIA Rendition, Detention, and Interrogation program-the so called "Torture Report." 24

Tetapi tampaknya ketiga presiden AS yang memerintah sejak dibentuknya penjara Guantanamo yang dimulai dari presiden George W. Bush (2001-2009), Barrack Obama (2009-2018) dan pada saat ini dibawah presiden Donald Trump,

${ }^{23}$ ACLU, Indefinite Detention, https://www.aclu.org/ diakses 11 Januari 2019

24 Patricia Stottlemyer, Looking For Justice? Avoid Guantanamo, Human Rights Firs, https://www.humanrightsfirst.org October 29, 2018 diakses 19 Januari 2019 
belum juga berhasil mengumpulkan alat bukti yang menunjukkan keterlibatan dan kesalahan dari kebanyakan para tahanan di Guantanamo ini, walaupun mereka telah mendekam selama belasan tahun di Guantanamo. Memang ada para tahanan yang sudah ditransfer kembali ke negara asal mereka, ada pula yang telah mengajukan tuntutan ganti rugi ke pemerintah mereka sendiri karena pemerintah meraka dianggap terlibat pelanggaran HAM terhadap mereka sewaktu ditahan di Guantanamo, seperti apa yang telah dilakukan oleh Omar Khadr, seorang warga negara Canada yang sempat mendekam selama 10 tahun sebelum akhirnya dibebaskan dari Guantanamo. 'Khadr was suing the government for $\$ 20 m$ on claims Ottawa conspired with the US in breaching his constitutional rights'. Khadr mengajukan gugatan sejumlah 20 juta dolar Kanada atas konspirasi antara Kanada dan AS dalam pelanggaran atas hak-hak konstitusionalnya. Akhirnya Omar Khadr mendapatkan ganti rugi \$8m dari pemerintah Canada yang disertai dengan permintaan maaf. ${ }^{25}$

Pemerintah Inggris dan Australia telah berhasil pula memulangkan warga negaranya dari Guantanamo, setelah melakukan perundingan-perundingan dengan otoritas AS. David Hicks yang merupakan warga negara Australia ditransfer ke Australia pada 18 Mei 2007. Hicks mengaku bersalah dan akan menjalani sisa hukumannya di Australia dan dibebaskan pada Desember $2007 .{ }^{26}$ Pemerintah Inggris juga sudah memberikan kompensasi finansial atas masa tahanan warga negara Inggris di Guantanamo setelah mereka dibebaskan. ${ }^{27}$

Bagaimana dengan upaya-upaya yang dilakukan oleh pemerintah RI terhadap Hambali, warga negaranya yang sudah hampir enam belas tahun berada di penjara Guantanamo yang keberadaannya telah dikecam oleh PBB, ICRC, NGO dibidang HAM sebagai tidak sesuai dengan hukum humaniter internasional dan hukum HAM internasional? Sampai saat ini otoritas AS belum juga bisa membuktikan kesalahan WNI tersebut di muka pengadilan dan masih ditahan tanpa batas waktu yang jelas dan kapan akan diajukan kemuka pengadilan.

25 BBC News, Canada 'paid $\$ 8 m$ ' to Omar Khadr, ex-Guantanamo detainee, https://www.bbc.co.uk/ 7 July 2001 diakses 11 Januari 2019

${ }^{26}$ The New York Times, The Guantanamo Docket, https://www.nytimes.com 11 Januari 2019

${ }^{27}$ Mary Dejevsky, Why was ‘compensation' paid to British Guantanamo Bay detainees and why are Blair and Blunkett now distancing themselves from the money?, Independent, https://www.independent.co.uk/ 23 February 2017, diakses 12 Januari 2019 
Sempat ada berita pada Juni 2017 bahwa Komisi Militer AS di penjara Teluk Guantanamo telah mengajukan dakwaan terhadap Hambali ${ }^{28}$, tapi tidak jelas bagaimana kelanjutannya. Pada Oktober 2018 ada lagi upaya untuk membawa Hambali ke Komisi Militer lagi ${ }^{29}$, tetapi sampai sekarang juga tidak ada beritanya apakah masih diteruskan atau tidak. Apakah pemerintah RI akan membiarkan warga negaranya mengalami perlakuan tidak manusiawi seperti yang dialami para tahanan Guantanamo lainnya juga?

Polri pernah mengirimkan anggotanya ke penjara Guantanamo untuk meminta keterangan kepada tersangka peledakan di sejumlah negara itu, tapi sampai sekarang belum jelas juga bagaimana tindak lanjutnya. ${ }^{30}$ Pemerintah RI tidak pernah menyampaikan permintaan resmi kepada AS untuk pemulangan Hambali ini. Yang diupayakan pemerintah via Kedutaan Besar RI Washington DC adalah akses kekonsuleran untuknya. ${ }^{31}$ Jadi kelihatan sekali kalau pemerintah RI bersikap pasif saja dalam persoalan Hambali di Guantanamo ini. Seharusnya pemerintah RI lebih bersikap pro aktif seperti yang diperlihatkan oleh pemerintah Austaralia dan Inggris dalam memulangkan warganegaranya. UU No.37 Tahun 1999 tentang Hubungan Luar Negeri mewajibkan Kementrian Luar Negeri untuk memberikan perlindungan kepada setiap WNI yang berada di luar negeri. Begitu juga dengan UU No.39 Tahun 1999, khususnya Pasal 71 yang mewajibkan Pemerintah RI untuk melindungi dan memajukan HHAM.

Seberat apapun tuduhan atau dakwaan terhadap Hambali yang diajukan oleh AS, dia tetap warga negara Indonesia yang menurut hukum patut diberikan perlindungan. Apalagi dia ditempatkan di penjara Guantanamo yang keberadaannya sendiri sangatlah kontraversial dan tidak manusiawi dimata masyarakat internasional. Pemerintah Obama sendiri mengakui perihal keburukan dari penjara Guatanamo ini dan telah berusaha untuk menutupnya, walaupun upaya penutupan ini tidak berhasil karena tidak mendapatkan dukungan dari

${ }^{28}$ BBC, Dalang Serangan Bom Bali Mungkin Bakal Disidang Di Mahkamah Militer AS, https://www.bbc.com 27 Juni 2017, diakses 19 Januari 2019

${ }^{29}$ Patricia Stottlemyer, Looking For Justice? Avoid Guantanamo, Human Rights First at https://www.humanrightsfirst.org October 29, 2018 diakses 19 Januari 2019

30 Kompas, Soal Hambali Polri koordinasi dengan Deplu, https://www.nasional.kompas.com 19 Januari 2010, diakses 12 Januari 2019

Tempo, Indonesia Tak Pernah Minta Hambali Dipulangkan, https://www.nasional.tempo.co/ 27 Oktober 2016, diakses 12 Januari 2019 
Kongres AS. Presiden Donald Trump yang menggantikan presiden Obama membuka kembali penjara Guantanamo dengan membatalkan keptusan presiden Obama.

Karena AS tidak berhasil menunjukkan bukti-bukti keterlibatan dan kesalahan Hambali selama belasan tahun ini, maka sudah waktunya Pemerintah RI meminta agar Hambali diserahkan kepada Indonesia. Pemerintah RI harus berupaya lebih maksimal lagi untuk memulangkan Hambali ke Indonesia dan mengadilinya dimuka pengadilan RI atas tindakan-tindakannya yang terkait dengan kasus Bom Bali dan peledakan hotel JW Marriot. Indonesia harus menunjukkan kepada dunia bahwa Indonesia adalah negara yang berdaulat dan sanggup mengadili tersangka teroris kelas berat sekalipun. Apalagi AS sampai dengan saat ini dibawah presiden Donald Trump bisa dikatakan tidak berhasil membuktikan kesalahan Hambali di muka Komisi Militer yang dibentuk oleh AS untuk mengadili para tersangka teroris yang bukan berkewarganegaraan AS.

Lima belas tahun ditahan tanpa proses peradilan dan diperlakukan secara tidak manusiawi merupakan sutu perbuatan yang melanggar hukum humaniter internasional dan hukum HAM internasional khususnya Pasal 9 (1) ICCPR tentang pelarangan atas penahanan tanpa batas waktu dan Pasal 9 (3) ICCPR tentang penahanan tanpa proses peradilan yang fair. Sudah tiba saatnya Indonesia tidak membiarkan terus berlangsungnya praktek yang tidak manusiawi dan merendahkan harkat dan martabat manusia di penjara Guantanamo. Perlakuan buruk AS ini harus dihentikan. Indonesia adalah negara beradab yang menghormati rule of law dan due process. Kalau pemerintah RI tidak segera melakukan upaya-upaya hukum dan diplomatik yang lebih aktif dan maksimal untuk menghentikan penahanan tanpa batas waktu dan tanpa proses peradilan ini maka pemerintah RI bisa dimintakan pertanggung jawabannya melalui forum internasional seperti the Human Rights Committee PBB dan juga melalui forum pengadilan dalam negeri sebagai perbuatan melawan hukum. Hambali dan keluarganya berhak melakukan upaya hukum ini. 


\section{PENUTUP}

Penahanan tanpa batas waktu dan tanpa proses peradilan yang fair yang sudah memakan waktu lebih kurang enam belas tahun terhitung sejak tahun 2003 serta perlakuan yang tidak manusiawi di penjara Guantanamo terhadap seorang WNI Hambali oleh AS jelas sekali merupakan suatu perbuatan melawan hukum. Penahanan ini telah melanggar baik itu norma-norma hukum domestik AS sendiri maupun norma hukum humaniter dan hukum HAM internasional. Berbagai pendapat hukum, baik itu yang dikeluarkan oleh PBB, LSM internasional yang bergerak dibidang HAM seperti Amnesty Internasional, Human Rights First dan Human Rights Watch sudah menjelaskan dan membuktikan hal itu.

Adapun yang menjadi persoalan sekarang adalah bagaimana mekanismenya untuk meminta pertanggung jawaban hukum atas pelanggaran terhadap hukum internasional yang telah dilakukan oleh AS tersebut. Kelihatannya hukum internasional menghadapi kendala yang serius dalam hal ini. Kelihatan sekali kalau hukum internasional itu tidak berdaya menghadapi negara adidaya seperti AS ini. Pada tataran domestik para tahanan di penjara Guantanamo ini bisa mengajukan tutntutan habeas corpus yang mempertanyakan keabsahan atau legalitas penahanan tersebut disertai tuntutan ganti rugi kemuka pengadilan domestik AS. Ada juga yang sudah berhasil mendapatkan ganti rugi atas tuntutannya itu seperti yang dilakukan oleh Omar Khadr warga negara Canada dan pemberian kompensasi yang dilakukan oleh pemerintah Inggris.

Bagaimana dengan tahanan Guantanamo yang berasal dari Indonesia seperti Hambali? Hukum domestik Indonesia sebenarnya bisa digunakan juga untuk meminta pertanggung jawaban hukum pemerintah RI di muka pengadilan domestik terkait dengan tindakan pemerintah yang tidak melaksanakan amanat UU No. 37/1999 tentang Hubungan Luar Negeri. UU ini mewajibkan kepada Kementrian Luar Negeri untuk melindungi WNI yang berada di luar negeri, tetapi Pemerintah RI kelihatan tidak maksimal dalam memberikan perlindungan terhadap Hambali sehingga dia harus berada di penjara Guantanamo selama lebih kurang enam belas tahuan, padahal para tahanan di Guantanamo tersebut telah menerima perlakuan tidak manusiawi, termasuk penyiksaan-penyiksaan dalam 
rangka untuk memaksa mereka memberikan pengakuan atas kejahatan yang dituduhkan terhadap para tahanan di Guantanamo itu.

Hambali dan keluarganya yang bermukim di Indonesia bisa mengajukan gugatan perbutan melawan hukum atas tindakan pasif dari pemerintah RI yang mendiamkan begitu saja tindakan-tindakan AS yang telah menahan dirinya tanpa batas waktu dan tanpa proses peradilan yang fair tersebut serta perlakuan yang tidak manusiawi, yang secara jelas telah melanggar hukum humaniter dan hukum HAM internasional seperti ICCPR yang telah diratifikasi oleh Indonesia. Tindakan pasif dari pemerintah RI ini juga bertentangan dengan UU No.39 Tahun 1999 Tentang Hak Asasi Manusia dalam pasal 71 yang mewajibkan pemerintah RI untuk melindungi dan memajukan hak asasi manusia.

Disamping pengadilan domestik di Indonesia, persoalan penahanan tanpa batas waktu dan tanpa proses peradilan yang fair serta perlakuan tidak manusiawi yang dialami Hambali di penjara Guantanamo ini juga bisa dibawa ke Human Rights Comittee (HRC), badan yang memonitor implementasi hak-hak yang dilindungi ICCPR oleh negara-negara peserta ICCPR. Adapun yang dipersoalkan adalah pasal 9 (1) ICCPR yang menyatakan bahwa: "Every One has the right to liberty and security of person. No one shall be subjected to arbitrary arrest or detention. No one shall be deprived of his liberty except on such grounds and in accordance with such procedure as are established by law."

Selain pasal 9 (1) ICCPR, yang juga bisa dibawa ke HRC adalah penahanan tanpa proses peradilan yang fair yang telah melanggar pasal 9 (3) ICCPR yang berbunyi: “Anyone arrested or detained on a criminal charge shall be brought promptly before a judge or other officer authorized by law to exercise judicial power and shall be entitled to trial within a reasonable time or to release. It shall not be the general rule that persons awaiting trial shall be detained in custody, but release may be subject to guarantees to appear for trial." Dalam pasal 9 (3) ini ditegaskan bahwa setiap orang yang ditangkap atau ditahan atas tuduhan pidana haruslah segera dihadapkan kemuka hakim atau pejabat yang diberi kewenangan oleh hukum untuk melaksanakan kekuasaan pengadilan dan berhak atas persidangan dalam waktu yang masuk akal atau dibebaskan. Janganlah dijadikan suatu ketentuan umum untuk menahan orang-orang yang 
20 ADIL: Jurnal Hukum Vol.10 No.1

sedang menunggu proses persidangannya, tetapi pembebasan bisa diberikan dengan syarat ada jaminan bahwa yang bersangkutan akan menghadiri persidangan. 


\section{DAFTAR PUSTAKA}

\section{Buku}

Duffy, Helen, The War On Terror and The Framework of International Law, Cambridge University Press, Cambridge, 2015.

Lowe, Vaughan, International Law: A Very Short Introduction, Oxford University Press, Oxford, 2015.

McGoldrick, Dominic, The Human Rights Committee: Its Role in the Development of the International Covenant on Civil and Political Rights, Clarendon Press, Oxford, 1994.

Slahi, Mohamedou Ould, Guantanamo Diary, Little Brown And Company, New York, 2015.

Townshend, Terrorism: A Very Short Introduction, Oxford University Press, Oxford, 2002.

\section{Internet}

Amnesty International, USA: Different label, same policy? Administration drop's 'enemy combatant' label in Guantanamo litigation, but retains law of war framework for detentions, 16 March 2009, https://www.amnesty.org/ diakses 10 Januari 2019.

CNN Library, Guantanamo Bay Naval Station Fast Facts, https://www.cnn.com September 11, 2018 diakses 12 Januari 2019.

Department of Justice, Final Report of the Guantanamo Review Task Force, https://www.justice.gov>2016 diakses 6 Januari 2019.

Gill, Terry and Sliedregt, Elies van, Guantanamo Bay: A Reflection On The Legal Status And Rights Of 'Unlawful Enemy Combatants', http://www.utrechtlawreview.org/ Volume 1, Issue 1 (September) 2005.

ICRC, Guantanamo Bay: Overview of the ICRC"s Work for Detainees, ICRC, $30 \quad$ January 2004, available at www.icrc.org/eng/resources/documents/misc/5qrc5v.htm..

Human Rights First, Dropped Charges, Overturned Convictions, and Delayed Trials in Guantanamo Military Commissions, https://www.humanrightsfirst.org 16 February, 2018 diakses 6 January 2019.

Human Rights First, Looking For Justice? Avoid Guantanamo by Patricia Stoottlemyer, October 29, 2018, available at www.humanrightsfirst.org diakses 7 Januari 2019. 
Human Rights Watch, Q\&A: Guantanamo Bay, US Detentions, and the Trump Administration, June 27, 2018, diakses 5 Januari 2019.

Kompas, Soal Hambali, Polri Koordinasi dengan Deplu, https://nasional.kompas.com 19 Januari 2010 diakses 12 Januari 2019.

Mary Dejevsky, Why was 'compensation' paid to British Guantanamo Bay detainees- and why are Blair and Blunkett now dustancing themselves from the money?, Independent, https://www.independent.co.uk/ 23 February 2017, diakses 12 Januari 2019.

Tempo, Indonesia Tak Pernah Minta Hambali Dipulangkan, https://nasional.tempo.co/ 27 Oktober 2016 diakses 12 Januari 2019.

VOA, Deplu: Hambali Ancaman Keamanan Tinggi Amerika, https://www. voaindonesia.com 18 Maret 2016 diakses 5 Januri 2019.

VOA, Belum Jelas Kapan Hambali Keluar Penjara Guantanamo, https://www. voaindonesia.com, 24 Agustus 2016 diakses 5 Januari 2019.

VOA, Napi Indonesia di Guantanamo Pertama Kali Tampil di Publik, https://www.voaindonesia.com 19/8/2016 diakses 5 Januari 2019.

VOA, Pemerintah Indonesia Belum Tentukan Sikap Soal Pemindahan Hambali, https://www.voaindonesia.com 18/9/2015 diakses 5 Januari 2019.

Zayas, Alfred de, Human Rights and Indefinite Detention, https://www.icrc.org diakses 12 Januari 2019. 